\title{
Multiple lymphoid nodules in bone marrow biopsy in immunocompetent patient with cytomegalovirus infection: an immunohistochemical analysis
}

\author{
Múltiplos nódulos linfóides na medula óssea de paciente imunocompetente \\ com infecção pelo citomegalovirus: uma análise imunohistoquímica
}

\author{
Silvia Maria Meire Magalhães ${ }^{1}$, Fernando Barros Duarte ${ }^{1}$, José Vassallo², \\ Sandra Cecília Botelho Costa ${ }^{3}$ and Irene Lorand-Metze ${ }^{3}$
}

\begin{abstract}
In Brazil, a high prevalence of cytomegalovirus (CMV) infection has been documented. In immunocompetent adults CMV infection is usually asymptomatic and therefore morphologic and immunophenotypic bone marrow changes have rarely been described. The authors report the case of a previously healthy patient who developed fever of undetermined origin. The diagnosis of acute CMV infection was based on serological testing. A computed tomographic scan showed mediastinal lymphadenopathy. A bone marrow biopsy revealed a hypercellular haematopoiesis with eosinophilia and large mixed T- and B-cell lymphoid aggregates. In spite of bcl-2 positivity, their reactive nature was demonstrated. Polymerase chain reaction $(P C R)$ and immunohistochemistry were unable to detect CMV-DNA in paraffin-embedded bone marrow sections. Much like in other systemic disorders, the lymphoid nodules in this case seemed to be caused by immunological mechanisms, possibly due to cytokines released in response to the systemic infectious process.
\end{abstract}

Key-words: Cytomegalovirus. Bone marrow. Lymphoid nodules.

Resumo Uma elevada prevalência de infecção pelo citomegalovírus (CMV) está documentada no Brasil. Em adultos imunocompetentes a infecção pelo CMV é, em geral, assintomática e, portanto, as alterações morfológicas e imunohistoquímicas na medula óssea têm sido raramente descritas. Relatamos o caso de um paciente previamente assintomático que desenvolveu febre de origem obscura. O diagnóstico de infecção aguda pelo CMV foi baseado em estudo sorológico. A tomografia computadorizada do tórax mostrou linfadenopatia mediastinal. A biópsia óssea revelou medula hipercelular com eosinofilia e grandes agregados linfóides mistos de células $B$ e T. Apesar da positividade para bcl-2, a sua natureza reacional foi demostrada. $A$ reação em cadeia da polimerase (PCR) e a imunohistoquímica não detectaram DNA viral nos cortes de medula óssea em parafina. Assim como em outros distúrbios sistêmicos, os nódulos linfóides no nosso caso parecem ser causados por mecanismos imunológicos, possivelmente relacionados a citoquinas liberadas em resposta ao processo infeccioso sistêmico.

Palavras-chaves: Citomegalovirus. Medula óssea. Nódulos linfóides.

Cytomegalovirus (CMV) is a common cause of viral infection and a major cause of morbidity and mortality in immunocompromised patients. Both primary infection and reactivation of endogenous latent virus owing to acquired immunodeficiency or immunosuppressive treatment can cause disease. The infection is associated with nonspecific bone marrow changes including myelosuppression and a florid haemophagocytic syndrome, especially in severe immunodeficiency ${ }^{4}$.
Nonimmunosuppressed patients rarely manifest clinical infection although CMV-induced thrombocytopenia and haemolysis have been reported ${ }^{14}$. CMV seroprevalence in adults ranges from $40 \%$ to $100 \%$ depending on geographical and socioeconomic conditions ${ }^{4}$. In Brazil, a high frequency of seropositivity has been reported ${ }^{5}$. Like other herpes virus, primary infection is followed by persistence of the virus in a latent form. It has been proposed that bone marrow progenitor cells and peripheral blood monocytes play a major role in the pathogenesis and latency of $\mathrm{CMV}^{15}$.

\footnotetext{
1. Department of Clinical Medicine/HEMOCE, Federal University of Ceará, Fortaleza, CE. 2. Department of Pathology, State University of Campinas, Campinas, SP. 3. Department of Clinical Medicine/State University of Campinas, Campinas, SP

Address to: Dra. Silvia Maria M. Magalhães. Centro de Hematologia e Hemoterapia do Ceará/HEMOCE/Universidade Federal do Ceará. Av. José Bastos 3390, 60436-160 Fortaleza,CE, Brasil

Fax:55 854334420

Recebido para publicação em 21/9/2000
} 
Reactive lymphocytic aggregates may be observed in marrow biopsies from patients with a wide range of infectious processes and immunological disorders. However, the distinction between benign and malignant proliferation based on morphologic criteria alone may be difficult. Although general guidelines for making this distinction are proposed, when lymphoid nodules are relatively large or numerous, immunohistochemical analysis has been shown to be useful in demonstrating their reactive nature ${ }^{13}$.

The present report describes the histopathological and immunohistochemical features of lymphoid aggregates in bone marrow of an immunocompetent patient who developed symptomatic CMV infection.

\section{CASE REPORT}

A 38-year-old man, previously healthy, reported bouts of fever without chills and fatigue in the last two months. The patient had a weight loss of $9 \mathrm{~kg}$. On physical examination no abnormality was found, except fever $\left(37.9^{\circ} \mathrm{C}\right)$. Laboratory findings included haemoglobin of $12.5 \mathrm{~g} / \mathrm{dl}$, a white blood cell count of $4.2 \times 10^{9} / \mathrm{L}$ with a normal differential count and platelet number. Erythrocyte sedimentation rate was $96 \mathrm{~mm}$. Anti-nuclear antibody testing was negative. Serologic analysis were negative for human immunodeficiency virus, EpsteinBarr virus, and for hepatitis $A, B$, and $C$. Infection with CMV was indicated by detection of markedly elevated CMV-specific lgM using enzyme-linked immunosorbent assay (ELISA). In peripheral blood, B-lymphocytes were
$6 \%$ (N: $15-30 \%$ ) and T cells were $74 \%$ (N: $65-74 \%$ ). Blood cultures for bacterial organisms were negative. $A$ computed tomographic scan of the chest showed slight mediastinal lymphadenopathy $(<1 \mathrm{~cm})$. The bone marrow biopsy revealed a hypercellular haematopoiesis with increase in eosinophils and multiple lymphoid nodules, including a poorly demarcated, large lymphoid expansion composed of small mature lymphocytes in the immediate paratrabecular area (Figure 1). No histological viral inclusions were seen. Immunohistochemical analysis of these aggregates was performed using the avidin-biotin-peroxidase complex, and monoclonal antibodies from DAKO, Denmark. A strong central positivity with CD20 and a positive
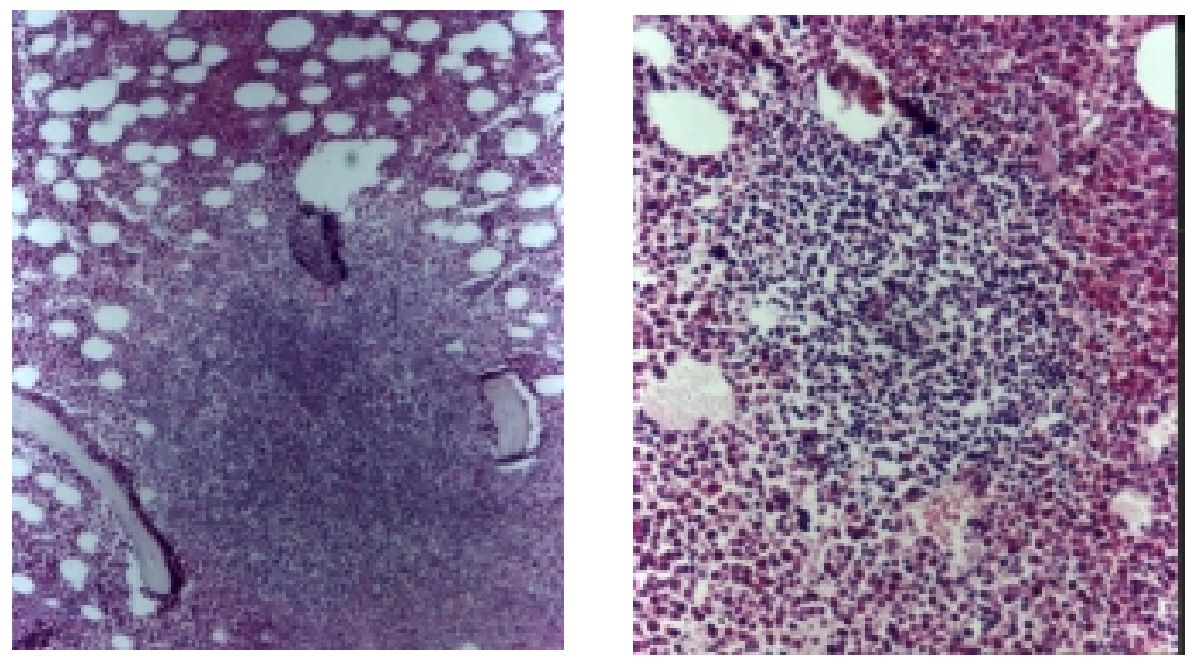

Figure 1 - Bone marrow biopsy section showing a poorly demarcated, large lymphoid aggregate in the immediate paratrabecular area (left) and a well circumscribed proliferation composed of small mature lymphocytes (right).

dispersed reaction with CD3 and CD45RO were observed (Figure 2). Staining with monoclonal antibody to bcl-2 was weakly positive. To investigate the possible presence of CMV-DNA the paraffin-embedded bone marrow was analysed by immunohistochemistry using primary monoclonal antibody against CMV delayed antigen. CMV-DNA was also determined using a nested polymerase chain reaction (PCR) with two pairs of primers, major immediate-early antigen (MIE) and immediate-early (IE), which correspond to conserved regions of the CMV genome. Specific primers for b-globin genes were used to ascertain the integrity of the extracted DNA and to detect any inhibition of polymerization in the extract. Both methods were unable to demonstrate the presence of CMV-DNA. One month later bouts of fever disappeared and white blood cell count raised to $7.3 \times 10^{9} / \mathrm{L}$. No specific therapy was given and the patient was still well 18 months after bone marrow examination. 

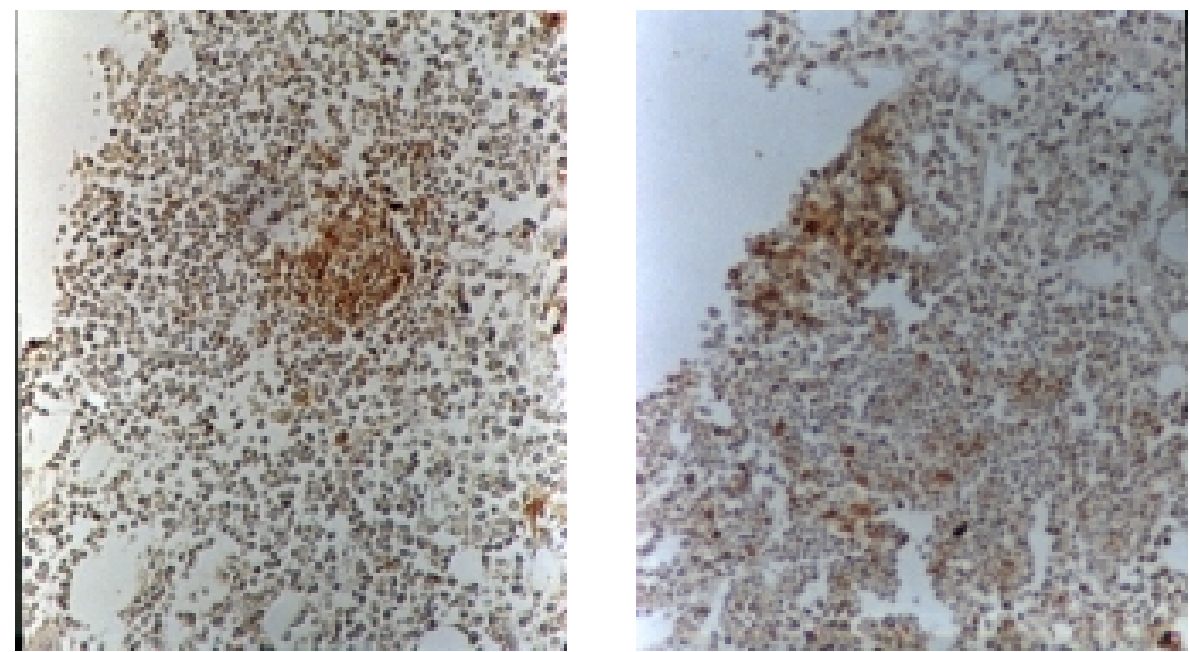

Figure 2 - Immunohistochemistry of bone marrow section, immunoperoxidase technique with hemotaxilin counterstain (left) Strong and central marking of lymphoid aggregate with monoclonal pan- $T$ antibody (CD45RO)

\section{DISCUSSION}

Infection with CMV rarely causes disease in immunocompetent individuals, except for a mononucleosis-like illness in some people ${ }^{7}$. However, in immunocompromised patients, most notably transplant-recipients and HIV-infected persons, CMV infection remains an important cause of illness associated with considerable morbidity and mortality ${ }^{4}$. Viral infection has been observed to cause suppression of haematopoiesis that may be mediated by CD8+ lymphocytes exposed to CMV, direct infection of myeloid progenitor cells, impairment of stromal cell function and decreased production of haematopoietic growth factors leading to leukopenia and thrombocytopenia ${ }^{4}$.

Lymphoid aggregates may be observed in bone marrow biopsy in a wide variety of viral infections but also in immune-related diseases and lymphomas. In the present case the diagnosis of acute CMV infection was based on clinical manifestations and serological testing. The patient presented a slight reversible leukopenia. However, bone marrow examination showed a hyperplastic granulopoiesis, with conspicuous increase in eosinophils. The large lymphoid aggregates observed were poorly circumscribed, had no germinal centre, and were mostly intertrabecular in position. Immunohistochemical analysis detected the presence of $B$ and $T$ lymphocytes, favouring their benign nature. Bcl-2 was weakly positive.

Differential diagnosis between benign and malignant lymphoid infiltrates may be difficult. In cases with a florid bone marrow lymphoid reaction, lymphoid aggregates may reach or line the bone trabeculae. Neoplastic lymphoid aggregates are usually composed of homogeneous $B$ cells but reactive $T$ cells may be observed in B-cell lymphomas ${ }^{8}$. In this topic, morphological features, including in particular histotopography and content of reticulin fibres, associated to immunohistochemistry are useful in differential diagnosis $^{13}$. It is worth mentioning that demonstration of immunoglobulin light chain restriction as a criterion of B-cell neoplasia using immunohistochemical analysis of paraffin tissue sections is of limited value. It has been primarily used in determining the monoclonal nature of plasma cell proliferation ${ }^{10}$ Molecular analysis, in spite of not always feasible, is helpful in proving monoclonality. Immunogenotypic approach, using the polymerase chain reaction (PCR) analysis of the unique immunoglobulin heavy chain on DNA extracted from routinely fixed trephine biopsies, can provide additional arguments in favour of lymphoid malignancy. However, because of the incomplete correlation between PCR data and immunomorphological findings resulting in low sensitivity rate, many authors have continued to consider morphology as a gold standard in evaluating bone marrow involvement by malignant lymphoma 310 . Therefore, immunogenotypic analysis is considered to be a useful and valuable complementary adjunct to morphology in the differential diagnosis of equivocal cases. In our case, the reactive nature of the lymphoid nodules was presumed by morphological and immunophenotypic features. On the other hand, the clinical manifestations completely reversed without specific therapy and the patient was followed for 18 months with no evidence of malignant disease. In agreement with previous reports, the bcl-2 expression was not a discriminatory criterion for distinction between benign and malignant nature ${ }^{612}$. 
The high sensitivity and specificity combined with rapid diagnosis make the molecular biology methods useful adjuncts to histology for detection of CMV-DNA ${ }^{11}$. However, in our case, both immunohistochemical and PCR studies performed on paraffin-embedded bone marrow specimen were negative. Therefore it seemed improbable that the changes found in bone marrow examination were due to a direct action of CMV on the haematopoietic tissue.
It has been demonstrated that CMV infection disturbs the balanced cytokine network that controls the proliferation and differentiation of haematopoietic cells ${ }^{9}$. The biologic significance of marrow lymphoid aggregates in the majority of patients is unknown. Their presence in our case seemed to represent a systemic response to the viral CMV infection.

\section{REFERENCES}

1. Arruda VR, Rossi CL, Nogueira E, Annicchino-Bizzacchi JM, Costa FF, Costa SCB. Cytomegalovirus infection as a cause of severe thrombocytopenia in a nonimmunosuppressed patient. Acta Haematologica 98: 228-230, 1997.

2. Ben-Ezra J, Hazelgrove K, Ferreira-Gonzalez A, Garret CT. Can polymerase chain reaction help distinguish benign from malignant aggregates in bone marrow aspirates? Archive Pathology Laboratory Medicine 124: 511-515, 2000.

3. Brinckmann R, Kaufmann O, Reinartz B, Dietel M. Specificity of PCR-based clonality analysis of immunoglobulin heavy chain gene rearrangements for the detection of bone marrow involvement by low-grade B-cell lymphomas. Journal of Pathology 190: 55-60, 2000.

4. De Jong MD, Galasso GJ, Gazzard B Griffiths PD, Jabs DA, Kern ER, Spector SA. Summary of the II International Symposium on Cytomegalovirus. Antiviral Research 39: 141-162, 1998.

5. Duarte G, Kawasaki E, Figueiredo, LTM, Yamamoto AY, Carlucci $\mathrm{RH}$. Estudo soroepidemiológico sobre citomegalovírus em parturientes e recém-nascidos. Revista Brasileira de Ginecologia e Obstetrícia 16: 153-158, 1994.

6. Fakan F, Skálová A, Kuntscherová J. Expression of bcl-2 protein in distinguishing benign from malignant lymphoid aggregates in bone marrow biopsies. General \& Diagnostic Pathology 141:359363, 1996.

7. Faucher JF, Abraham B, Segondy M, Jonquet O, Reynes J, Janbon F. Cytomegalovirose acquise de l'adulte immunocompetent: 116 observations. Presse Medicale 27: 1774-1779, 1998.

8. Horny HP, Wehrmann M, Griesser H, Tiemann M, Bultmann B, Kaiserling $\mathrm{E}$. Investigation of bone marrow lymphocyte subsets in normal, reactive, and neoplastic states using paraffin-embedded biopsy specimens. American Journal of Clinical Pathology 99: 142149, 1993.

9. Lagneaux L, Delforge A, Snoeck R, Bosmans E, Schols D, De Clereq E, Stryckmans P, Bron D. Imbalance in production of cytokines by bone marrow stromal cells following cytomegalovirus infection. Journal of Infectious Diseases 174:913-919, 1996.

10. Maes B, Achten R, Demunter A, Peeters B, Verhoef G, De WolfPeeters $C$. Evaluation of $B$ cell lymphoid infiltrates in bone marrow biopsies by morphology, immunohistochemistry and molecular analysis. Journal of Clinical Pathology 53: 835-840, 2000.

11. Rawlinson WD. Broadsheet. Number 50: Diagnosis of human cytomegalovirus infection and disease. Pathology 31: 109-115, 1999.

12. Skálová A, Fakan F. Bcl-2 protein does not help to distinguish benign from malignant lymphoid nodules in bone marrow biopsy specimens. Journal of Clinical Pathology 50: 87-88, 1997.

13. Thiele J, Zirbes TK, Kvasnicka HM, Fischer R. Focal lymphoid aggregates (nodules) in bone marrow biopsies: differentiation between benign hyperplasia and malignant lymphoma - a practical guideline. Journal of Clinical Pathology 52: 294-300, 1999.

14. Van Spronsen DJ, Breed WPM. Cytomegalovirus-induced thrombocytopenia and haemolysis in an immunocompetent adult. British Journal of Haematology 92: 218-220, 1996.

15. Von Laer D, Meyer-Koenig U, Serr A Finke J, Kanz L, Fauser AA, Neumann-Haefelin D, Brugger W, Hufert FT. Detection of cytomegalovirus DNA in CD34+ cells from blood and bone marrow. Blood 86: 4086-4090, 1995. 